\title{
REVELAÇÕES DO MOMENTO DE TRANSITORIEDADE DA COMUNICAÇÃO CONTEMPORÂNEA NA SÉRIE TELEVISIVA “TUDO O QUE É SÓLIDO PODE DERRETER".
}

REVELATIONS OF THE MOMENT OF TRANSIENCE OF MODERN CULTURE IN THE

TELEVISION SERIES "ALL THAT IS SOLID MELTS CAN".

REVELACIONES DEL MOMENTO DEL TRANSITORIEDAD DE LA COMUNICACIÓN CONTEMPORÁNEA EN LA SERIE DE TELEVISIÓN “TODO LO SOLIDO SE PUEDE

DERRETIR”.

\author{
Daniela Gomide \\ Mestranda UNESP - SP \\ danielagomide@hotmail.com
}

\section{Resumo}

Partindo do momento pós-industrial, no qual as características sociais e tecnológicas trazem implicações culturais e complexidades conceituais para o campo da comunicação, trataremos neste artigo das manifestações que surgem em tal contexto a respeito deste momento de transitoriedade que a sociedade contemporânea atravessa. A partir da análise da série televisiva Tudo o que é sólido pode Derreter, utilizando a Teoria das Mediações de Jesus Martín-Barbero, buscaremos identificar elementos que caracterizam a postura difusa do sujeito diante do atual cenário, comparando tal objeto a uma fonte literária a qual serviu de fundamento para a elaboração da citada série.

Palavras-chave: análise audiovisual, transitoriedade, literatura.

\begin{abstract}
Leaving of the postindustrial moment, in which the social and technological characteristics bring cultural implications and conceptual complexities for the field of the communication, we will treat in this article of the manifestations that appear in such a context regarding this moment of transitoriness that the contemporary society crosses. Starting from the analysis of the television series Everything that is solid can Melt, using the Theory of the Mediations of Jesus Martín-Barbero, we will look for to identify elements that characterize the subject's diffuse posture before the current scenery, comparing such object to a literary source which served as foundation for the elaboration of the mentioned series.
\end{abstract}

Key Words: audiovisual analysis, transitoriness, literature. 


\section{RESUMEN}

A partir del momento post-industrial en el que las características sociales y tecnológicas traen implicaciones culturales y complejidades conceptuales para el campo de la comunicación, trataremos en este artículo de las manifestaciones que surgen en este contexto, a esta hora de la transitoriedad que la sociedad contemporánea está experimentando. A partir del análisis de la serie de televisión "Todo lo solido se puede derretir" y utilizando la teoría de Las Mediaciones de Jesus Martín-Barbero tratan de identificar los elementos que caracterizan la postura difusa del sujeito en el contexto actual comparando este objeto a una fuente literaria que sirvió de base para el desarrollo de esa serie.

Palabras clave: analisis audiovisual, transitoriedad, literatura

O constante revolucionar da produção, a ininterrupta perturbação de todas as relações sociais, a interminável incerteza e agitação distinguem a época burguesa de todas as épocas anteriores. Todas as relações fixas, imobilizadas, com sua aura de idéias e opiniões veneráveis, são descartadas; todas as novas relações, recémformadas, se tornam obsoletas antes que ossifiquem. Tudo o que é sólido desmancha no ar, tudo o que é sagrado é profanado, e os homens são finalmente forçados a enfrentar com sentidos mais sóbrios suas reais condições de vida e sua relação com outros homens." (MARX, apud BERMAN, 93)

\section{INTRODUÇÃO}

O rápido desenvolvimento tecnológico dos meios de comunicação colocou em prova muitos conceitos utilizados na definição de produção, conteúdos e disseminação da comunicação. As discussões epistemológicas se tornam obsoletas diante da rapidez das transformações e das possibilidades que os novos meios proporcionam à comunicação. Neste contexto, a própria comunicação se torna um conteúdo, uma manifestação da percepção que temos a respeito da nossa realidade.

Buscamos eleger um objeto contido na televisão para estudar como os conteúdos estão sendo pensados e construídos pela instância de produção comunicacional. Para tanto analisamos uma série que foi baseada em um curta-metragem, cujos produtores foram descobertos por uma produção de grande repercussão na internet. Portanto, o curta-metragem cujo nome também é Tudo o que é sólido pode Derreter, incitou uma rede televisiva a produzir uma série. Este processo do seriado, então embrionário, foi importante principalmente por já contextualizar a realidade midiática.

O objeto analisado foi elaborado em treze episódios, cujos títulos são os mesmos das obras literárias utilizadas em seu corpo. Neste artigo, não nos ateremos ao estudo da relação 
das obras que compõe o seriado e suas possíveis produções de sentido, uma vez que buscaremos verificar a maneira como a série faz a captação do momento de transitoriedade da contemporaneidade e os conflitos que trazem este momento. Porém é válido explicitar que a série possui respectivamente os títulos, Auto da Barca do Inferno, de Gil Vicente; Os Sermões, de Padre Antonio Vieira, Os Lusíadas, de Luis de Camões; A Canção do Exílio, de Gonçalves Dias; Senhora, de José de Alencar; Macário, de Álvares de Azevedo; Dom Casmurro, de Machado de Assis; Ismália, poema de Alphonsus de Guimarães; Quadrilha, poema de Carlos Drummond de Andrade; O livro dos prazeres, de Clarice Lispector; e, Macunaíma, de Mario de Andrade.

Utilizaremos para a análise o episódio quatro, sob o título de Canção do Exílio, que aborda a temática dos problemas sociais decorrentes das noções sobre o espaço e o tempo na nova realidade virtual, pois além de possibilitar uma leitura mais dinâmica, traz um resumo de problemáticas sociais que vão desde a corporeidade até os limites do espaço, os quais são modificados com as novas mídias. Os demais episódios também nos possibilitariam uma fértil análise, porém, para este artigo teremos que reduzir a análise a apenas um capítulo. Portanto, a escolha do episódio foi feita por meio da predileção da temática sobre o estrangeirismo, uma vez que este assunto retrata a sensação de não pertencimento do indivíduo ao mesmo tempo em que busca identidades para se auto-afirmar em uma terra desconhecida. Para a análise da narrativa audiovisual utilizamos a metodologia proposta por Francisco Javier Goméz Tarín, que oferece ferramentas de leitura do texto audiovisual facilitando a reflexão do processo de interpretação e concepção subjetiva sobre o trabalho hermenêutico.

A narrativa audiovisual da série dialoga com autores da literatura clássica estabelecendo analogias sobre as principais problemáticas das obras com outras da atual conjuntura e que são vividos pela protagonista. E, não somente dialoga com os autores, como também tem sua principal fundamentação na obra literária Tudo o que é sólido desmancha no ar, de Marshal Berman, e, não fortuitamente, possui o título e sua narratividade convizinha à série, conforme poderemos analisar neste artigo.

\section{A PERCEPÇÃO DA TRANSITORIEDADE MANIFESTADA NA MÍDIA}

A sensação de "transitoriedade" que a sociedade contemporânea vivencia é percebida principalmente através dos suportes tecnológicos que tiveram um desenvolvimento muito 
rápido em relação à própria história da humanidade. Em menos de um século assistimos a popularização da geladeira, da televisão, dos computadores e da telefonia, destacando o desenvolvimento desta última que em dez anos permitiu um processo de migração comunicacional, saindo do que MacLuhan chamou de "meio frio" em direção a um meio "híbrido" e nos apresentando uma convergência dos meios de comunicação. Nessa direção, o telefone móvel possibilitou o acesso à internet e à televisão, que foram considerados pelo autor canadense como "meios quentes", além da comunicação direta através da interação do sujeito com o meio (a telefonia propriamente dita), o que MacLuhan chamou de "meio frio".

Porém, com a união dos meios em um único instrumento temos agora uma nova característica que torna o meio algo "híbrido" (Heims, apud Vilches, 2003). Sobre tal fenômeno, enfocar-se-á-lo naquilo que diz respeito às comunicações e seus meios, pois neste momento de transitoriedade o mesmo se mostra como efeito de todas as relações humanas que hoje utilizam, de alguma forma, ferramentas tecnológicas - sejam elas direcionadas ao transporte, alimentação, estudo, política ou a qualquer atividade humana onde o ponto de fruição se dá através, ou com a interferência, de algum meio tecnológico. Percebemos que este momento pode ser uma forma permanente em todas as relações entre os meios e a sociedade e, principalmente, também no campo da comunicação, uma vez que as ferramentas tecnológicas utilizadas pela sociedade contemporânea são também altamente voláteis e praticamente "mutantes" em comparação às suas formas antecessoras. Trata-se de uma situação semelhante às outras, de grandes mudanças sociais e culturais, atravessadas pela humanidade onde a comunicação também foi campo de manifestação e condução de tal transitoriedade.

Na série Tudo o que é sólido pode derreter é possível perceber traços que fazem referência a esse momento de mudança social, uma vez que, analisando a abertura do programa, notamos a semelhança não somente com o título do livro de Marshal Berman, Tudo que é sólido desmancha no ar, mas também com as ilustrações e formas utilizadas em capa, os quais, por sua vez, fazem alusão à obra de Kasemir Malevich ${ }^{2}$.

\footnotetext{
${ }^{1}$ Pode-se definir como um meio quente, aquele que prolonga um único de nossos sentidos em alta definição, em saturação de dados e "meios frios" seriam aqueles que seriam aqueles que prolongam um único sentido e em "baixa definição" (baixa saturação de dados). O encontro de dois meios (o híbrido), constitui um momento de verdade e revelação, do qual nasce a forma nova. (McLuhan, 1996. p. 67 - 75).

${ }^{2}$ Kasemir Malevich foi um pintor abstrato soviético, fez parte da considerada vanguarda russa e mentor do movimento suprematista, o qual se centra em formas geométricas básicas. O suprematismo foi considerada como a primeira escola sistemática de pintura abstrata do movimento moderno.
} 


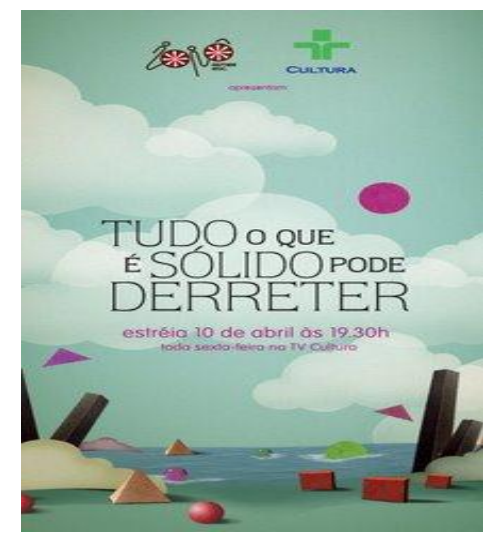

Figura 1- Abertura do programa Tudo o que é sólido pode derreter.

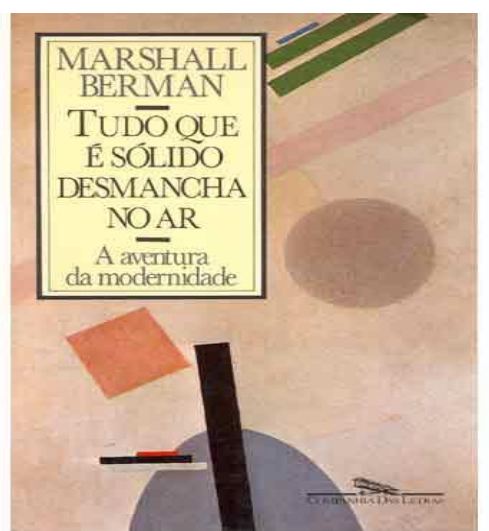

Figura 2- Capa do Livro de Marshal Berman, Tudo o que é sólido desmancha no ar. São Paulo, Schwarcz, 2001.

Tais referências são ditas justamente pelo conteúdo do livro de Berman, o qual discorre sobre as ambiguidades do mundo moderno e sobre a origem da modernidade com a conseqüente dissolução dos laços tradicionais de lealdade e fidelidade pessoal, além do desenvolvimento da idéia de razão, quando o homem se viu compelido a pensar e a agir sobre o mundo. Para Berman, o homem já não era mais visto como fruto do sopro ou palavra divina, mas, parafraseando o Fausto de Goethe, através da "ação" do próprio homem. A cidade passa a ser o espaço principal em que irão se desenvolver as novas formas de relações sociais específicas da modernidade.

Comparando o conteúdo do livro ao atual contexto, percebemos a semelhança na inquietude entre os pensadores e sujeitos dos dois períodos. Como ocorreu no modernismo, atualmente passamos por um momento de transitoriedade que propõe novas possibilidades econômicas e comerciais, com variadas formas de relações sociais, diferente noção de espaço e tempo e principalmente uma aceleração comunicacional. Se no livro de Berman, há as discussões entre os autores e intelectuais da época sobre as novas possibilidades de convivência, onde as noções de espaço foram alteradas, em nosso atual cenário também nos é apresentada uma singular percepção de espaço principalmente decorrente do ciberespaço. Tais mudanças são manifestadas em diferentes meios, como na literatura, no cinema ou nos conteúdos televisivos. Sob esta ótica buscamos analisar o conteúdo da série traçando um paralelo ao conteúdo do livro de Berman.

$\mathrm{Na}$ série, a qual nos propomos analisar e utilizar como objeto de estudo, é possível verificar que, a protagonista, uma garota adolescente, vive conflitos não somente referentes à sua idade, mas relativos aos modelos de relações sociais que são conduzidas atualmente. Interessante destacar que neste momento de convergência dos meios e multimeios, os adolescentes são a geração que conduzirão o desenvolvimento tecnológico, possuindo maior participação principalmente nas mídias sociais que edificam as novas formas de relações sociais. 
Na série podemos verificar a postura da protagonista em relação ao "espaço-tempo" em que vive, pois ela não se sente à vontade com as novas maneiras de relacionamento, ora mediados pela internet, ora superficiais ou efêmeros. Ela questiona alguma forma destacada de relação humana, desde a amizade, profissão e sexo. Constatamos através dos diálogos que a protagonista tem consigo mesma, em seu imaginário, que embora não entenda e muitas vezes não aprove as situações em que ela é colocada, que ela se sente uma buscadora de sentido. Evidenciamos tal semelhança apresentada por Berman com a série exatamente neste episódio, no qual a protagonista explora o desejo pelo novo, pela mudança, a contestação e a rebeldia inseridos dentro da era globalizada.

A protagonista, Thereza, inicia o episódio escrevendo em seu blog sobre o período incômodo pelo qual passou na semana anterior, mostrado do fotograma 3 ( fotograma extraído do texto audiovisual). Inicia narrando, em voz off, sua própria experiência, o que caracteriza, dessa forma, o narrador como autodiegético e que sinaliza o discurso como expressão de objetividade marcante. Outro sentido percebido é que as imagens exibidas colocam o espectador como leitor do blog, pois o ângulo se fixa na tela do computador, enquanto a protagonista escreve. As imagens que retratam esse momento da narrativa conduzem o receptor à sensação de usuário da internet, além de espectador da série a qual está assistindo. O movimento da câmera direciona o olhar do espectador de acordo com o olhar da protagonista, conduzindo o foco para a tela do computador, conforme demonstrado no fotograma 4. Esse início é muito importante porque retrata exatamente a convergência dos meios e a transitoriedade em que estes próprios meios se interceptam na busca por uma identidade. Interessante dizer que o blog é uma ferramenta utilizada na internet e que possibilita a qualquer individuo, que detenha um saber inicial em informática e acesso à rede, manifestar qualquer forma de conteúdo e informação. É uma das maneiras atuais de estabelecer vínculos sociais que dispensam o conhecimento real do sujeito com quem se relaciona.

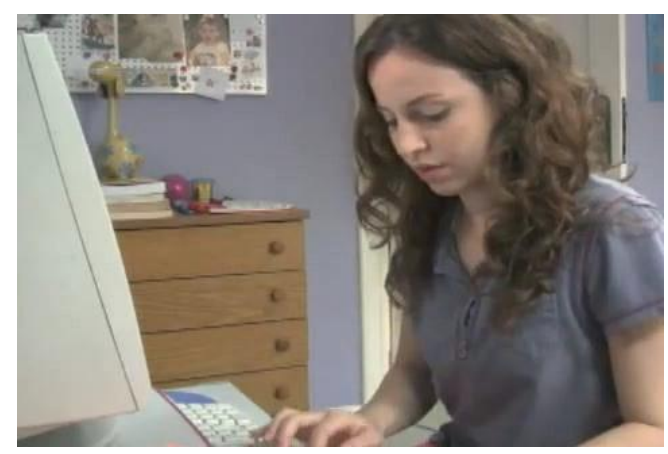

Fotograma 3- Protagonista escreve em seu blog. Imagem audiovisual produzida pela televisão.

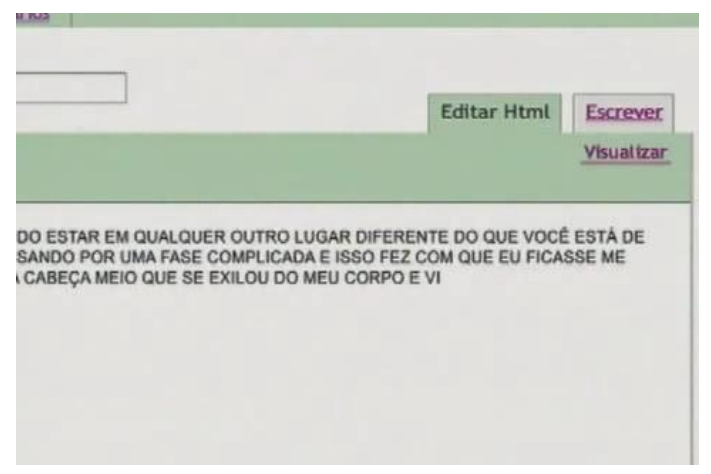

Fotograma 4- O blog sendo mostrado através da televisão, que conduz o espectador à "ler" o blog e assistir à série.

ANIMUS R. Interamericana de Comunicação Midiática, nttp://www.utsm.or/revistas 
Ao estudar o livro de Berman é percebida a mesma inquietude em relação ao comportamento social e as definições a respeito do desenvolvimento tecnológico. Berman relata em seu livro o pensamento sobre o desenvolvimento tecnológico que poderia trazer o aprisionamento aos homens, mas que sendo eles capazes de entender tal cárcere poderiam combatê-lo. Segundo Berman, homens como Marx, Nietzsche e todos os grandes críticos do século XIX e XX “chegam a compreender como a tecnologia moderna e a organização social condicionaram o destino do homem" (BERMAN, pag,26). Interessante ressaltar que Berman coloca uma citação de MacLuhan publicada em 1964 onde, o autor analisando o contexto no qual experencia, conjetura a função da tecnologia, especificamente do computador, afirmando que tal ferramenta poderá ultrapassar a barreira da linguagem e atingir a todos, além de dispensar a figura física.

[...] o computador em poucas palavras, promete através da tecnologia a possibilidade pentecostal de entendimento e unidade universais. O próximo passo lógico parece ser [...] ultrapassar as linguagens em favor de uma generalizada consciência cósmica. [...] A condição de ausência de peso que, segundo os biologistas, representará a imortalidade física, deve ser posta em paralelo com a condição da ausência da fala, que poderá significar a perpetuidade da paz e harmonia coletiva (MacLuhan, apud BERMAN, p.25).

Estendendo a análise de Tudo o que é sólido pode Derreter é percebido que a narrativa foi construída utilizando o tempo passado, contando um fato que já ocorreu. A atualização do "blog" pessoal de Thereza como diário é uma das ferramentas que demonstram esta condição temporal. Outro elemento que revela a intenção de retrospectiva, ou seja, que começa a conduzir o espectador para o tempo passado, é a imagem fixa de mastros em uma planície onde as nuvens se movimentam rapidamente causando a impressão de passagem de tempo ( fotograma 5). Essa imagem é reforçada pelo som elaborado com uma música que imita a sonoridade de um relógio e as enunciações com os dias da semana que estabelecem o cronograma da ordem dos acontecimentos. Percebemos que a marcação do tempo nesta narrativa objetiva ultrapassar a simples sucessão de acontecimentos e demonstrar a inexistência dele neste novo cenário, onde as mudanças parecem ser "aceleradas".

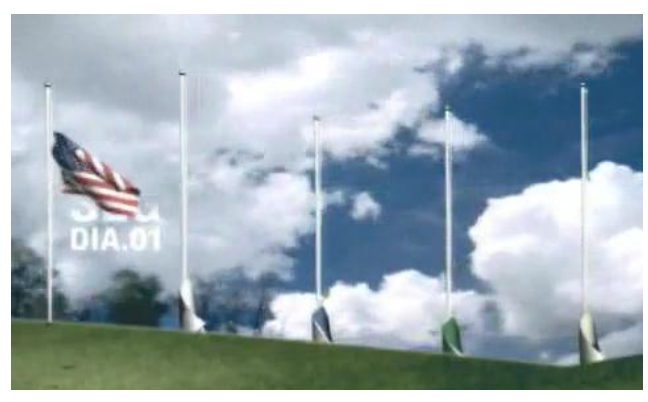

Fotograma 5 - mastros no início do texto audiovisual indicando o passar dos dias da semana com a enunciação verbal e os países nos quais a nicação Midiát [ protagonista buscou morar.

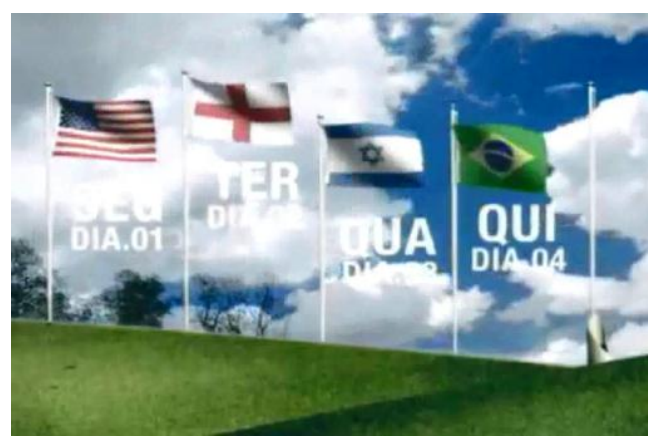

Fotograma 6 - mastros no final do texto audiovisual indicando o passar dos dias da semana com a enunciação verbal e os países nos quais a !02 protagonista buscou morar. 
A narrativa conta que Thereza estava menstruada, numa semana impaciente com a vida na metrópole, irritada na escola e dentro da sua própria casa. Influenciada por amigas com quem mantém contato via internet e também por acontecimentos de seu cotidiano, sente vontade de morar em outro país. Aborrece-se na aula de Matemática com o fato de ter de decorar fórmulas, não entendendo sua real utilidade, quando o professor ensina um versinho da Canção do Exílio, o que faz com que os alunos decorem a fórmula de seno e cosseno mais facilmente. Os versos ficam na cabeça de Thereza e ecoa em suas buscas reais e virtuais. Thereza inicia um blog e repensa, através das experiências das amigas e da obra de Gonçalves Dias, os valores do mundo em que habita.

Estabelecendo uma relação com o poema Canção do Exílio, Thereza conversa com o autor Gonçalves Dias em seu imaginário e busca entender a razão de ter escrito tais versos. Tal como ele, a protagonista se sente uma "estrangeira" e busca identificação com outras nacionalidades. Importante ressaltar que ela "encontra" o autor através de uma rede social da internet, onde há o "perfil" de Gonçalves Dias, demonstrado através do fotograma 6. A partir deste ponto, a narrativa ocorre alterando entre o imaginário de Thereza e a realidade, deixando inclusive à predileção do espectador a definição de realidade. No fotograma 7 vemos à exemplo desta fusão de realidade com imaginário, o autor Gonçalves Dias solicitando à Thereza autorização para ingressar em sua rede social virtual.

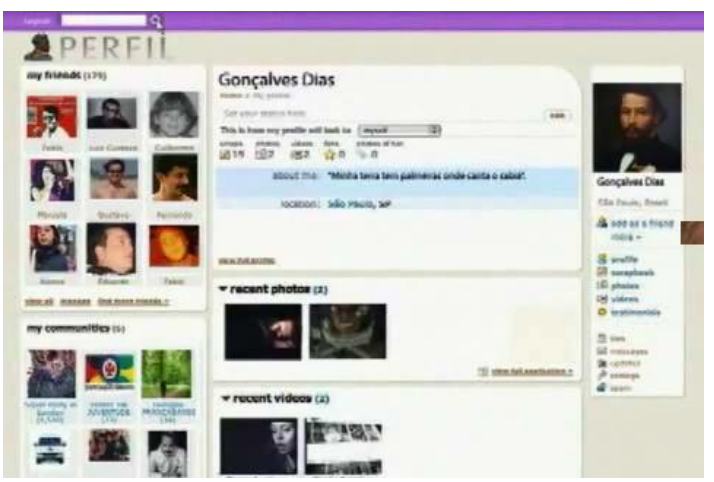

Fotograma 7- perfil de Gonçalves Dias em um programa de relacionamentos na internet.

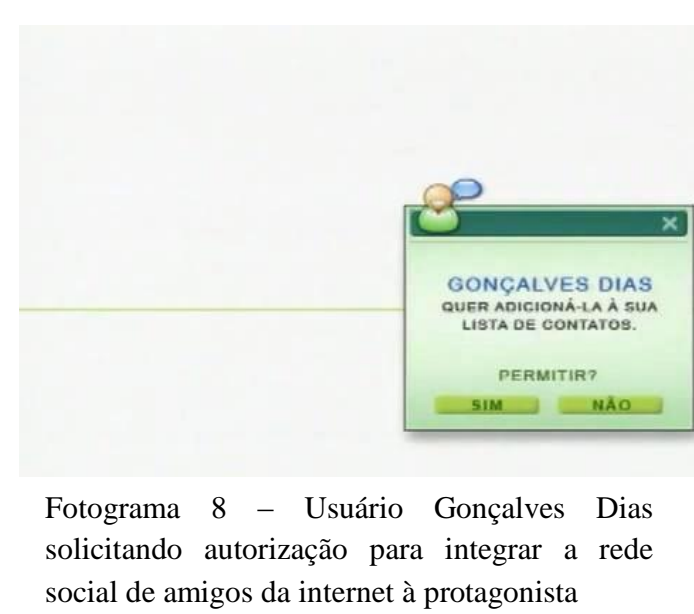

As conversas entre Thereza e suas amigas, brasileiras, mas que residem no exterior, especificamente em Israel e Estados Unidos, ocorrem na internet. Com a personagem Kitty, amiga que reside em Nova York, e com a qual mantém uma relação virtual, pois a protagonista a conheceu no Brasil, viu-a pessoalmente apenas uma vez. Já Noa, que está em 
Israel, volta periodicamente ao Brasil, mas muda de país conforme as transferências profissionais do pai. Ambas as relações são estabelecidas pelo novo contexto econômico e social que é vivenciado nos dias atuais.

O texto audiovisual retrata essas relações da protagonista mostrando imagens das telas do computador que explicitam os programas de mídias sociais tornando possíveis conversas com visualização dos indivíduos residentes em posições geográficas distantes e em horários diferentes, mas que no ambiente virtual se assemelham ou até mesmo se equiparam, conforme é visto na fotograma 8 . No desenvolvimento da trama os diálogos na internet ocorrem de forma constante, de modo a instigar a protagonista a ir para os países onde as amigas estão demonstrando a busca da protagonista por um lugar onde ela se sinta parte de uma sociedade. Estes diálogos são mostrados com o ângulo fixo na tela do computador e inclusive reproduzem o ruído de imagem que o programa do computador faz quando é utilizado, representado pelo fotograma 9. A câmera da televisão faz o papel da "webcam" ou câmera do computador, pela qual as imagens são captadas e enviadas simultaneamente.

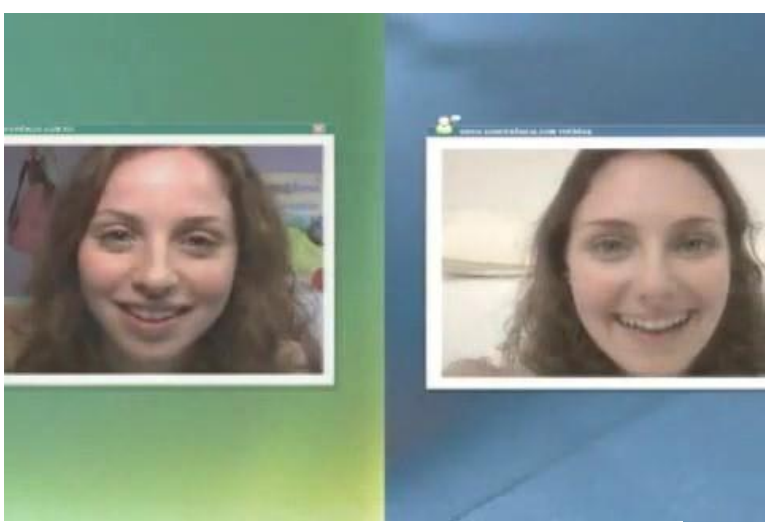

Fotograma 9 - Thereza conversando com a amiga kitty através de uma mídia social.

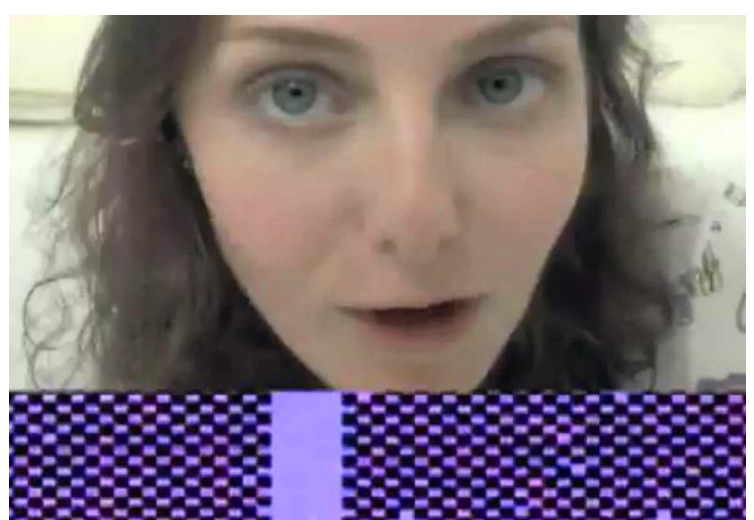

Fotograma 10 - Câmera do texto audiovisual fazendo o papel de webcam reproduzindo os ruídos de imagem que ocorrem no computador.

Interessante destacar que a sequiência da narrativa alterna os diálogos que a protagonista tem com as amigas e seu imaginário. Para marcar essa transição de uma lugar ao outro, as imagens do imaginário da protagonista trazem um recurso que deixa ao redor do enquadramento um elemento semelhante à fumaça.

No momento em que o professor de matemática declama o verso com a mesma sonoridade e rimas da Canção do Exílio, mas com as palavras referentes à matéria em questão, Thereza é surpreendida pela queda de um copo, que estava sedo usado em uma 
brincadeira em sala de aula, ela assusta e fecha os olhos, ao abrir os olhos ela está em seu imaginário, que apresenta uma ilha, na qual ela mesma tenta se localizar. Há na ilha apenas uma palmeira e um homem que inicia um dialogo em inglês com ela. A cena é composta com uma música ao fundo ( musica "Banheira" de Nathália Malo) que possui uma musicalidade semelhante à músicas havaianas, ou seja, remete à férias, praia, mar e viagem ou neste caso, a navegar. A protagonista estabelece um diálogo com o homem que se identifica como Robson Crusué, natural do Reino Unido, na mesma cena ela avista o tio ${ }^{3}$ no meio das águas,representadas por papéis azuis. Ela pergunta a Robson sobre a existência do tio na ilha e o tio mesmo responde que "navegar é preciso", verificado no fotograma 10. Toda esta cena é apresentada em planos aberto e fechados, deixando o enquadramento no rosto do personagem que detém a voz no diálogo. Ao final da cena, acompanhando a fala do tio Augusto, a câmera se movimenta imitando os movimentos da maré e abrindo o plano.

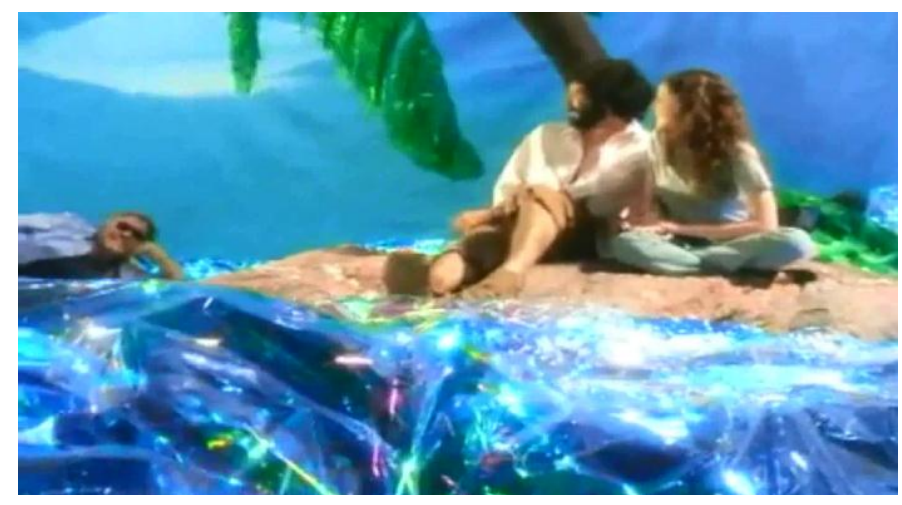

Figura 11 - Protagonista na ilha imaginária com Robson Crusué e o tio Augusto.

Ao sair da escola, ela retorna para casa e em seu quarto ela discute com a mãe, o que lhe deixa mais irritada. A mãe ao deixar o quarto deixa Thereza sozinha, e a narrativa audiovisual introduz novamente a música de Nathalia Malo, ouvida na primeira viagem ao seu imaginário, e a voz off do tio dizendo a mesma frase "navegar é preciso Thereza". A protagonista então senta-se em frente ao computador para conversar com as amigas.

Thereza entra na rede de relacionamentos e a amiga Noa, que está em Israel lhe chama e pede para que ela verificar um site ( fotograma 11). Ao "clicar" no site ela é direcionada à uma rede de brodcast com um vídeo de imagens de guerra. $\mathrm{O}$ ângulo desta cena é fixo na tela

\footnotetext{
${ }^{3} \mathrm{O}$ tio foi um ator frustrado, morto por volta dos 45 anos de idade. Foi, em vida, o grande mentor de Thereza, contando coisas engraçadas e curiosas, ensinado-a a ver o lado menos óbvio do mundo. Sempre foi a pessoa preferida da protagonista, a quem ela pode recorrer em momentos de dúvida. Aparece em flashbacks ou na imaginação de Thereza, pontuando acontecimentos da vida da sobrinha.
} 
do computador mostrando todas as ações de Thereza na internet e no momento em que o vídeo é iniciado o ângulo se fecha e ele passa a ser representado pela câmera audiovisual ( sequencia dos fotogramas 12, 1314 e 15). Mais uma vez a câmera da televisão assume o papel da tela do computador. Nesta cena há apenas o som de uma sirene tocando e a câmera passa a ser subjetiva.

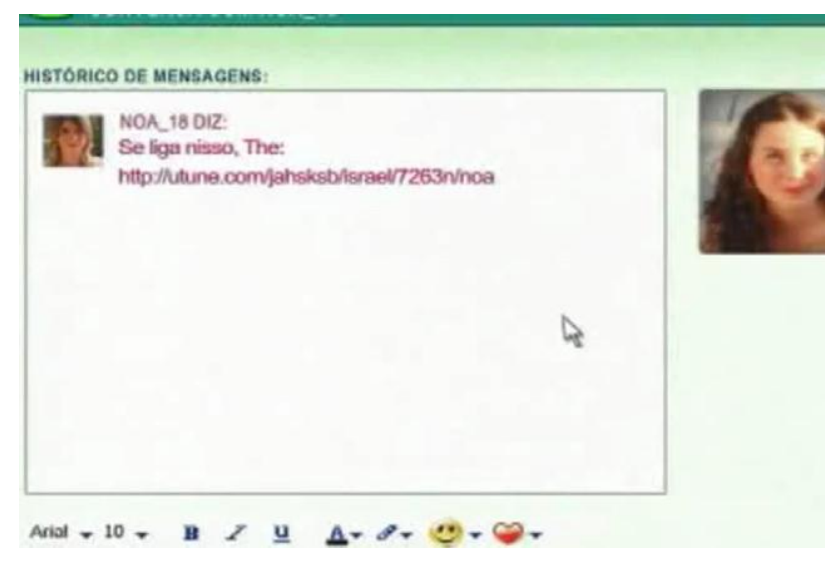

Fotograma 12 - Tela do computador mostrada pela tela da televisão, onde a amiga Noa convida Thereza a entrar em um site.

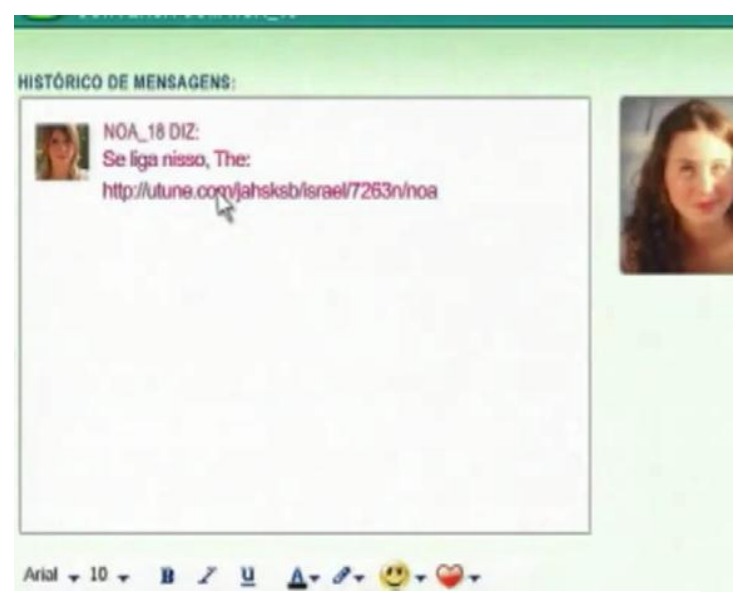

Fotograma 13 - Thereza movimenta a seta com o mouse e clica sobre o link do site.

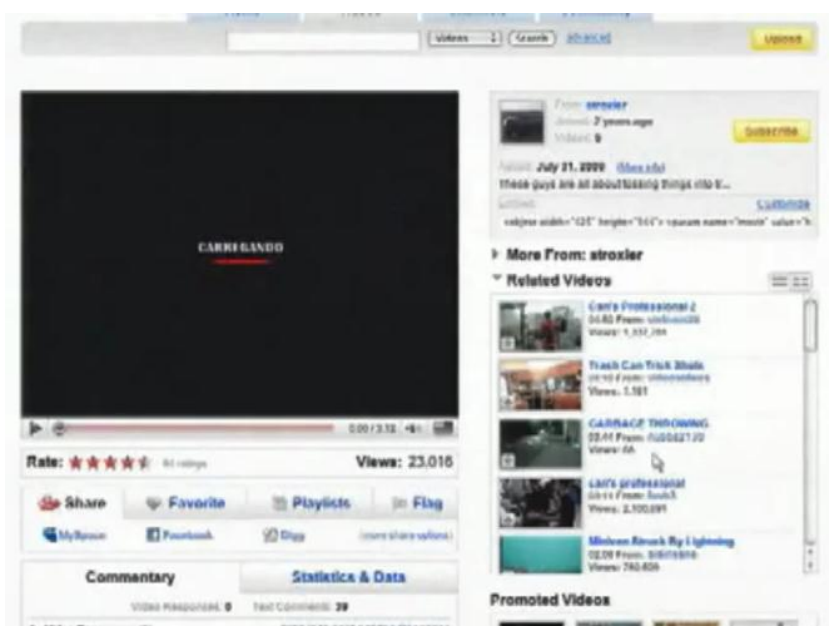

Fotograma 14 - Site brocast o qual Thereza foi convidada a verificar.

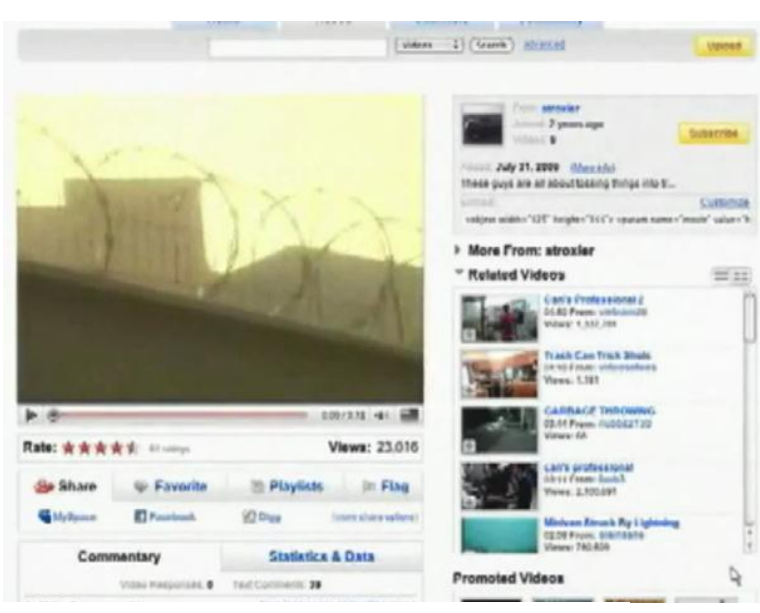

Fotograma 15 - Vídeo sendo inciado no site. 


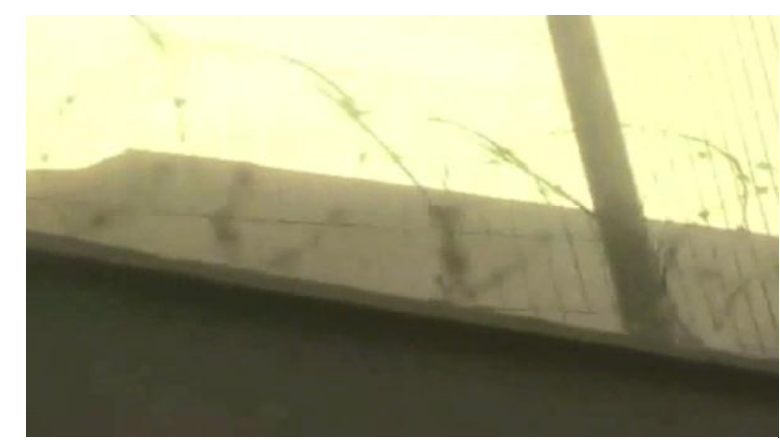

Fotograma 16 - O vídeo do site em plano fechado, ou seja, quando o audiovisual se transforma em tela do computador.

Thereza é interrompida pela campainha e ao atender descobre que os pais estavam vendendo o carro. Enquanto ela aguarda a mãe vir até a sala para acertar o negócio da venda do carro o comprador conversa com ela, mas ela está voltada para seus pensamentos. Ela recorda uma carta escrita pelo tio, quando ele ainda era vivo, a respeito de uma viagem, na qual ele ainda está no avião, portanto narra como está sendo a experiência. Essa cena é composta pelo tio narrando a carta em voz off, e elementos compositores do plano surgem sobre a cabeça de Thereza em forma de aviões. O plano é aberto mostrando os dois personagens, Thereza e o comprador que mantém a fala, percebida pelo movimentar da boca dele, mas a sonoridade mantém-se apenas com a voz off do tio.

Ao retornar ao computador, a protagonista se depara com uma solicitação de permissão para manter uma conversa através da mídia social. Essa solicitação é feita por uma pessoa com o nome de Gonçalves Dias, conforme ilustrado na figura 16. Intrigada, ela busca informações sobre essa pessoa com uma amiga, pensando ser um menino que conheceram em uma festa. Ela interrompe o telefonema com a amiga, pois o absorvente vazou e ela teve que tomar banho. Essa cena é em plano fechado com ângulo fixo no rosto da protagonista alternando o ângulo apenas para mostrar a amiga Letícia com quem ela mantém o dialogo. Em um momento o enquadramento é dividido e as duas personagens são mantidas na tela, mas esse enquadramento é interrompido e novamente voltado para Thereza no momento em que ela se irrita com a menstruação.

No banho, os ângulos são fechados em elementos que o representam deixando somente o som referente ao elemento. Há a representação do ralo, com água escorrendo, o chuveiro, com água caindo, o adesivo do absorvente sendo tirado e a calça sendo vestida. Thereza novamente volta ao seu quarto e sentada em frente ao computador busca em uma mídia social o perfil de Gonçalves Dias ( fotograma 17). O ângulo se fecha e a tela da televisão passa a ser a do computador. Aparecem a foto de Gonçalves Dias e uma frase principal de perfil; " Minha terra tem palmeiras onde canta o sabiá" demonstrado pela fotograma 18 e 19. Em voz off, Thereza pensa sobre a frase novamente aparecer em sua vida. 
Novamente Gonçalves Dias solicita permissão para ser adicionado à sua rede de relacionamentos e ela aceita. $\mathrm{O}$ ângulo é fechado no canto da tela demonstrado a aceitação.

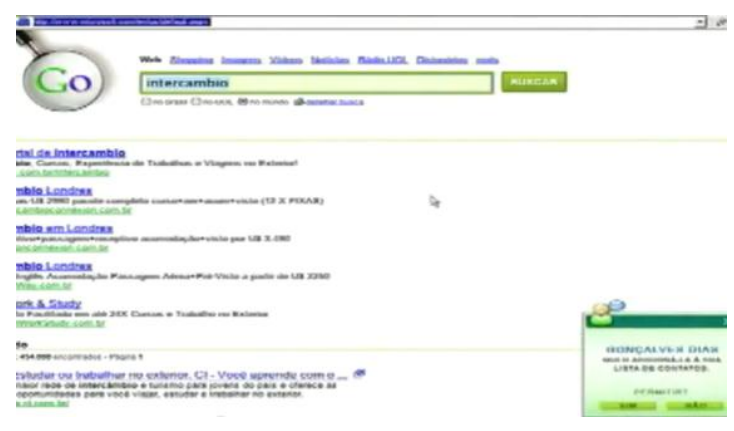

Fotograma 17 - Tela do computador no momento em que Golçalves Dias pede permissão para ser aceito na rede social de Thereza.

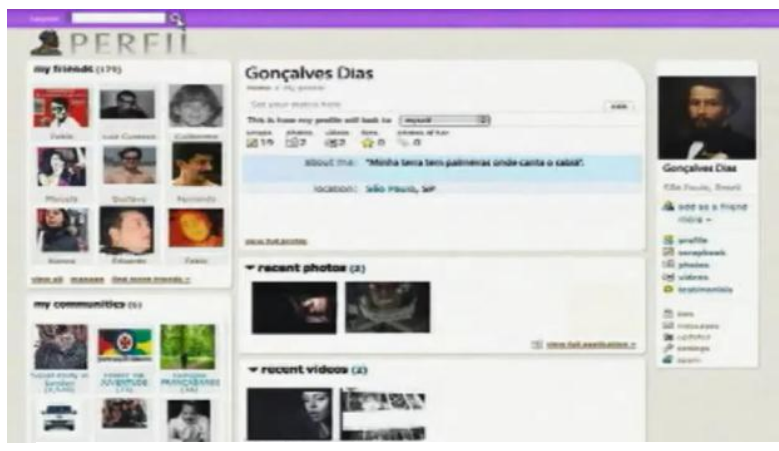

Fotograma 18- Tela do computador representando a página do perfil de Gonçalves Dias em uma mídia social.

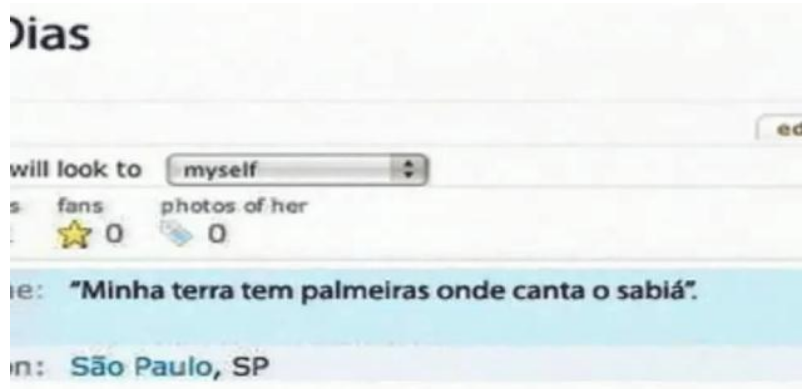

Fotograma 19- a frase principal do perfil de Gonçalves Dias em uma mídia social.

Toca-se uma sirene e ela verifica na tela o chamado de Noa. O vídeo, o qual ela havia iniciado continua e a câmera inicia as imagens do vídeo como subjetiva e se torna um traveling no momento em que Thereza aparece na cena seguida da amiga Noa. Inseridas nas imagens do vídeo, conforme fotograma 20, elas estabelecem um dialogo a respeito da vida em Israel. O dialogo acontece na internet, mas o vídeo é utilizado como cenário para esta conversa, uma vez que todo o dialogo ocorre em ambiente virtual. Noa explica à protagonista que o vídeo é a respeito de um abrigo anti bombas, mas que Israel seria um país perfeito caso não houvesse as bombas.Thereza questiona o fato da amiga estar de uniforme, e ela explica que o exercito é obrigatório à todos no país. Elas se sentam e pensam em ir morar com a amiga Kitty em Nova York, ao ouvirem uma bomba Thereza fecha os olhos e a sequiência é direcionada ao quarto dela novamente. 


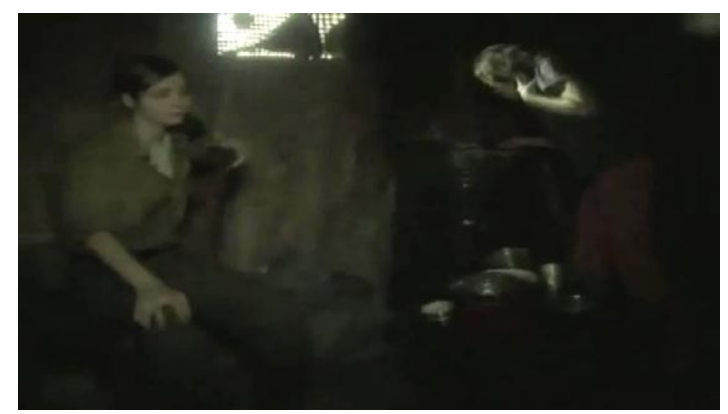

Fotograma 20 - vídeo iniciado através da internet e que serve de cenário para o diálogo entre Thereza e a amiga.

$\mathrm{Na}$ conversa final da protagonista com as amigas, as imagens passam a ser representadas por construções do imaginário de Thereza e não mais pelas telas do computador. Na narrativa a protagonista e suas amigas estabelecem uma "sala de bate papo" que de acordo com o dialogo estabelecido entre elas "fica" na casa de kitty.Neste momento o usuário chamado Gonçalves Dias pede permissão para entrar na "sala" .Esta representação é exposta como uma sala inteira branca, transmitindo o sentido de "território neutro" ou mesmo de "ciberespaço". O autor, então entra na "sala" e declama os versos da Canção do Exílio, ilustrado pelo fotograma 21. As imagens que acompanham a narração do poema por Gonçalves Dias são de Thereza se relacionando com seus amigos, que residem no Brasil, em diferentes momentos e em diversos lugares que freqüentam, fazendo alusão à "terra onde canta os sabiás", ou seja, trazendo à memória da protagonista a sensação de pertencimento à uma nação. Com esse conhecimento Thereza compreende que se sentir uma "exilada" era mais uma questão de inquietude interna do que não pertencimento ao lugar geográfico como ela acreditava.

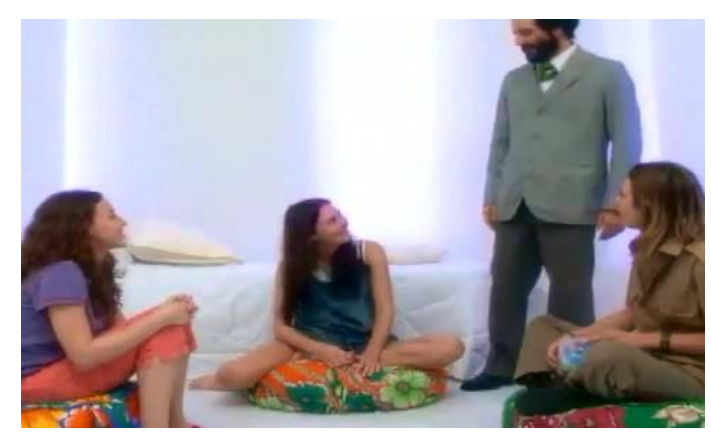

Fotograma 21- Gonçalves Dias na "sala de bate papo da internet" com as personagens da série.

A inquietude da transitoriedade é iniciada no episódio com questões fisiológicas, pois a protagonista está menstruada e aprendendo a lidar com as alterações que este momento traz na vida de uma mulher. Concomitantemente, seus pais enfrentam um período econômico 
difícil, o que coloca em pauta a realidade econômica a qual ela pertence e suas possibilidades futuras dentro desta realidade. As amigas aparentemente não vivenciam problemas sociais e econômicos, pois estão vivendo em outros países, onde o contexto figura-se diferente. Todas essas questões a respeito de diferenças econômicas e sociais se encontram no espaço comum, o "ciberespaço", que propicia a troca de experiências entre as personagens e ao mesmo tempo as inserem em um contexto de falta de identidade. O clímax do episódio traz essa reflexão da protagonista buscando estabelecer um sentido para a impressão de estrangeirismo.

O final do episódio é uma narração em voz off, da protagonista explicando a vida do autor Gonçalves Dias e sua geração, esta fala é marcada pelas imagens que mostram a protagonista com o autor, como se eles fossem amigos, deixando mais uma vez sobre o espectador a sensação de fusão entre realidade e imaginário ( fotogramas 22 e 23).

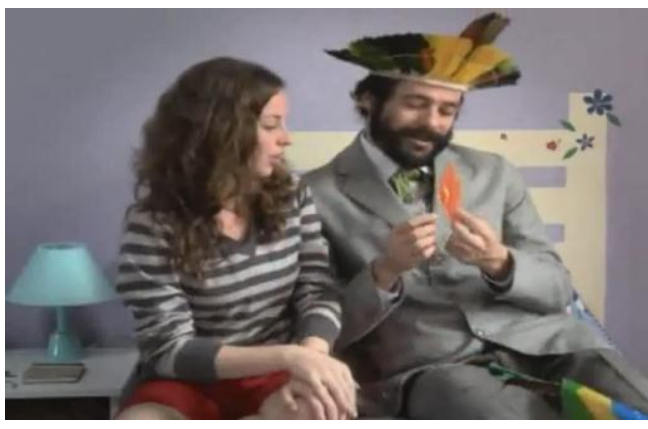

Fotograma 22- Thereza com Gonçalves Dias

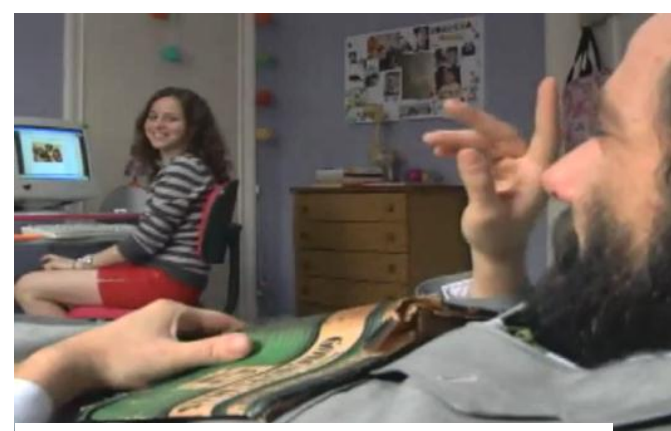

Fotograma 23- Thereza com Gonçalves Dias.

Diante deste cenário, podemos identificar no conteúdo da série que propomos analisar, os questionamentos a respeito desta realidade colocados de forma quase inocente por uma adolescente que procura através do ato da leitura identificação com outros sujeitos.

Na narratividade do episódio analisado há a repetição da famosa frase de Fernando Pessoa, "é preciso navegar". Ao conhecer esta frase, Thereza busca um significado para identificar-se com o autor. Quando ela adquire conhecimento a respeito da situação do escritor ao compor a obra Canção do Exilio, ela cria uma identidade sobre a sensação de estar em um lugar e não se sentir pertencente a ele. E então unindo à história de Gonçalves Dias à frase de Fernando Pessoa ela consegue estabelecer o sentido sobre a possibilidade que ela possui na atual realidade de "navegar" pela internet, o que lhe possibilita a ampliação ou criação do seu mundo (com a criação de um blog). Buscando a identidade entre sua realidade e a do autor, ela adapta a linguagem erudita de Gonçalves Dias e Fernando Pessoa à sua, estabelecendo um sentido para seu contexto.

Analisando o conteúdo do livro de Bermam e o conteúdo das mensagens da série, percebemos que há em ambos a narração de conflitos em uma época de mudanças sociais, 
econômicas e comerciais. Destacamos que a utilização da literatura na série, não é, portanto, somente em seu conteúdo explícito, mas compõe a edificação da sua estrutura enquanto objeto de comunicação que expõe determinada cultura.

\section{A ANÁliSE AUDIOVISUAL DA SÉRIE E A TEORIA DAS MEDIAÇÕES}

Diante deste contexto que a sociedade vivencia, alicerçado sobre o desenvolvimento tecnológico, principalmente quando tratamos de mensagens destinadas a adolescentes, não nos ateremos às discussões sobre a convergência dos meios, mas sobre a questão que coloca essa própria discussão como comunicação dos meios para com o todo. Ou seja, a discussão sobre a transitoriedade, suas consequiências e suas possibilidades que são constituintes do momento pelo qual passamos. E sobre este aspecto há a necessidade em nos ater, não somente nos debates epistemológicos do campo da comunicação, mas na maneira como passaremos por este momento, produzindo conhecimentos que irão auxiliar a sociedade a passar de um pólo ao outro. E neste momento, como o desenvolvimento tecnológico leva a sociedade a uma era "informacionalista", há a necessidade de percebemos como estão sendo manifestadas, através do conteúdo que é transmitido pelos meios, as insatisfações, preocupações da sociedade em relação ao momento.

Por esta razão, para constatarmos a captação que a mídia faz da realidade e vice e versa, utilizamos a Teoria das Mediações de Barbero, que é centrada na observação do espaço simbólico ou representativo que medeia a relação entre emissor e receptor e assim, "o eixo do debate deve se deslocar dos meios para as mediações, isto é, para as articulações entre práticas de comunicação e movimentos sociais, para as diferentes temporalidades e para a pluralidade de matrizes culturais" (MARTIN-BARBERO, 2002, p. 55). Desta forma, podemos constatar que o conteúdo demonstrado na série Tudo o que é sólido pode derreter não traz somente uma semelhança com o conteúdo do livro de Berman e sim uma representação da realidade de um campo social.

Barbero, em primeira instância, observou que os meios de comunicação não configuram o ser humano num receptor passivo e alheio à sua própria realidade, ou seja, a mídia não institui e delimita uma relação unilateral entre um emissor dominante e um receptor dominado, pois entre esses dois pólos há uma intensa troca de intenções na cadeia comunicacional. Portanto, há entre a produção de um conteúdo midiático e sua recepção um "espaço" onde a cultura desenvolvida por ambas as instâncias (recepção e emissão) contribuí e dita o conteúdo da mensagem comunicacional. Desta forma, enquanto Berman coloca as 
inquietações sociais durante o modernismo em seu livro, podemos verificar que as discussões sobre o momento de transitoriedade constante que vivemos, são refletidas nos meios de comunicação.

A circulação dos novos meios de propagação e produção de elementos culturais é condicionada pelas tecnologias da comunicação. Estas trabalham em harmonia com a sensibilidade e as formas de percepção do povo, que dotado de sentido, interpreta a mensagem a partir do seu repertório sociocultural. Dessa forma:

Pensar os processos de comunicação neste sentido, a partir da cultura, significa deixar de pensá-los a partir das disciplinas e dos meios. Significa romper com a segurança proporcionada pela redução da problemática da comunicação à das tecnologias" (MARTÍN-BARBERO, 2000, p. 297).

$\mathrm{O}$ ato de mediar significa fixar entre duas partes um ponto de referência comum, mas eqüidistante, que a uma e a outra faculte o estabelecimento de algum tipo de inter-relação, ou seja, as mediações seriam estratégias de comunicação em que, ao participar, o ser humano se representa a si próprio e o seu entorno, proporcionando uma significativa produção e troca de sentidos.

Portanto, queremos estabelecer que a discussão aqui objetivada não significa direcionar a investigação dos processos comunicacionais à desorganização epistemológica, pois, segundo Ilana Polistchuk e Aluízio Ramos Trinta (2003, p. 147-148) "significa centrálo em um eixo sociocultural, pelo qual estão em causa as leituras" (os processos individuais e coletivos de dotação de sentidos) que cada um faz do que é destinado a todos.

Os mecanismos de manipulação, que prevêem e prescrevem reações, apontados pelas teorias de recepção tradicionais, não são ignorados por Martín-Barbero. Na verdade, ele denuncia a eminente interação entre a Indústria Cultural e os seus consumidores e destaca que as tecnologias não são apenas "parafernália da era eletrônica", constituindo-se em organizadoras da percepção, tanto no plano da existência individual como na esfera da vida coletiva.

\section{CONSIDERAÇÕES FINAIS}

Produzimos a sociedade e por ela somos produzidos. Com base neste entendimento podemos ancorar a mudança de estrutura na complexidade que tal dinâmica nos mostra, aprendendo a lidar com as incertezas e as verdades transitórias. Ao fazermos esse percurso, podemos articulá-lo através da interdisciplinaridade para criar estratégias de reconhecimento 
dos sujeitos frente ao mundo diverso, plural, que acolhe espaços e o ciberespaço, especialmente diante da mobilidade que nos faz contar pequenas histórias a cada fricção de tempo. O cenário que se vislumbra nos faz entender que somos parte de um sistema complexo, múltiplo, rizomático e sem núcleo comum. Cibercultura, virtualidade e transdiciplinaridade pelo viés do pensamento complexo são eixos estruturantes deste sistema que se entrelaça por meio do caráter transitório.

O entendimento da transitoriedade das informações e do conhecimento, neste ambiente, nos leva a perceber este caráter que descreve dois aspectos complementares: aquilo que transita, ou seja, está em movimento constante entre agentes e, por outro lado, refere-se também ao que não é perene, estável, que não se consolida. Ao que parece transparecer pelas relações neste percurso é que os modelos que temos, estruturados em um mundo sólido, biocorporal, onde a realidade é dada por objetos estáveis, visíveis e comuns (BOCCARA, in LEÃO, 2005), não se sustentam frente ao espaço comunicativo e todas as suas potencialidades.

A construção de sentido é constituída a partir de totalidades parciais, a partir de critérios pertinentes, mas não temos solidez e volume, temos mobilidade, mutações e devires. Talvez isto nos torne, lembrando Baudelaire, "um viajante de passagem”. Somos receptores e potenciais emissores de uma relação de fluxo de mensagens planetária, multimodal. "Formamos um ecossistema complexo com nossos objetos técnicos" (LEMOS, 2005: 261). Como na série e no livro, essa transitoriedade é sólida e por isso pode desmanchar, derreter ou talvez ser apenas "deletado".

\section{Referências}

BARBOSA, João Alexandre. As Ilusões da modernidade. São Paulo: Perspectiva, 1996.

BERMAN, Marshall. Tudo que é sólido desmancha no ar: a aventura da modernidade. São Paulo: Companhia das letras, 1986.

CANCLINI, Néstor Garcia. Culturas híbridas. São Paulo: Edusp, 2003.

CAPRA, Fritjof. As conexões ocultas: ciência para uma vida sustentável. São Paulo: Editora Cultrix, 2002. 
CASTELLS, Manuel. A era da informação: economia, sociedade e cultura. A sociedade em rede. São Paulo: Editora Paz e Terra, 2006.

GOETHE, J. W. Fausto. São Paulo: Editora Nova Cultural, 2003.

JENKINS, Henry. Cultura da Convergência. São Paulo:Aleph, 2009.

LEÃO, Lúcia (Org). Derivas: cartografias do ciberespaço. São Paulo: Senac, 2004.

LEMOS, André. Cibercultura, tecnologia e vida social na cultura contemporânea. Porto Alegre: Sulina, 2005.

LÉVY, Pierre. Cibercultura. 4ªedição. São Paulo: Editora 34, 2003.

MCLUHAN, Marshall. Os meios de comunicação como extensões do homem. São Paulo: Cultrix, 1996.

MELO, José Marques de; ROCHA, Paulo da (org). Comunicação, cultura e mediações: o percurso intelectual de Jesús Martín-Barbero. São Bernardo do Campo: Umesp,1999.

MARTIN-BARBERO, Jesús. Comunicação e mediações culturais. Revista Brasileira de Ciências da Comunicação, vol XXIII, número 1. São Paulo, 2000.

América Latina e os anos recentes: o estudo da recepção em comunicação social. In: SOUSA, Mauro Wilton (org.). Sujeito, o lado oculto do receptor. São Paulo: Brasiliense, 2002.

POLISTCHUK, Ilana; TRINTA, Aluizio Ramos. Teorias da Comunicação: o pensamento e a prática da Comunicação Social. Rio de Janeiro: Campus, 2003. 
TARÍN, Francisco Javier Gómez e CAMILO, Eduardo J.M. Saberes para compartir.

Estudios de comunicación:analisys y retos tecnológicos.Covilhã: Universidad de Beira Interior, 2007.

VILCHES, Lorenzo. A migração digital. São Paulo: Loyola, 2003.

http://www.tvcultura.com.br/tudooqueesolido/index.php

Original recebido em: 30/08/2011

Aceito para publicação em: 29/11/2011

Resumo do Autor:

Daniela Dias Gomide Possui graduação em comunicação social- habiltação jornalismo pela Universidade Estadual Paulista Júlio de Mesquita Filho (2006). Tem experiência na área de Comunicação, com ênfase em Marketing empresarial e jornalismo especializado.

http://buscatextual.cnpq.br/buscatextual/visualizacv.do?id=K4202789D3 